\title{
ESSENTIAL OIL YIELD IN EUCALYPTUS CITRIODORA IN RELATION TO FOLIAGE AGE AFTER POLLARDING AND TREE AGE
}

\author{
Gu $\mathrm{Y}^{1,2}$, Yang $\mathrm{L}^{2}$, Huo $\mathrm{HQ}^{3}$, Zhou $\mathrm{LZ}^{2}$, Wen $\mathrm{RS}^{2} \&$ Zhu $\mathrm{YJ}^{1, *}$ \\ ${ }^{1}$ School of Economics and Management, Beijing Forestry University, Beijing 100083, China \\ ${ }^{2}$ Guangxi Forestry Research Institute, Nanning 530002, China \\ ${ }^{3}$ Mid-Florida Research and Education Center, Department of Environmental Horticulture, University of Florida, FL 32703 , \\ USA \\ *13641397119@163.com
}

Submitted December 2018; accepted March 2019

\begin{abstract}
In a series of field experiments in subtropical south China, Eucalyptus citriodora leaf biomass, essential oil yield and composition were measured in relation to tree age, different pruning treatments and foliage age following pollarding. The dominant compounds in the essential oil included citronellal $(76.9 \%)$, citronellol $(7.5 \%)$, isopulegol $(6.4 \%)$ and neoisopulegol $(3.1 \%)$. The 3- and 5-year-old trees yielded the most essential oil (4.4 and $4.7 \%$ respectively) and citronellal (82.6 and $82.5 \%$ respectively), and yield decreased with tree age. One year following the pruning treatments, foliage biomass was three times greater from 1, 2 and $3 \mathrm{~m}$ high stumps than from coppiced trees and $0.5 \mathrm{~m}$ high stumps. Oil yield was highest for trees pollarded at $1 \mathrm{~m}$ (equivalent to $5.9 \%$ from dry leaves) and lowest from coppiced trees (3.2\%). All pollarding treatments yielded more citronellal $(79.3-81.9 \%)$ than coppiced trees $(66.0 \%)$. Oil yield and citronellal content were higher (5.9 and $77.7 \%$ respectively) when harvested at 12 months than at 6 months, 2, 3, 4 and 5 years after pollarding. Based on our results, harvest of fresh E. citriodora leaves should begin 3-5 years after planting, with a 1-year harvest interval, and pollarding above $1.0 \mathrm{~m}$ for optimal oil yield.
\end{abstract}

Keywords: Citronellal, rotation cycle, coppice, foliage biomass, gas chromatography-mass spectrometry

\section{INTRODUCTION}

Eucalyptus citriodora (Myrtaceae), commonly called lemon-scented eucalyptus, is a fast-growing ornamental tree species planted for timber and oil production. The essential oil extracted from its leaves is used in food, pharmaceutical, dailyuse chemical and fragrance products (Tripathi et al. 2008, Bello et al. 2013). The oil has been used for sterilisation, as an insect repellent (Singh et al. 2011), and for its anti-inflammatory and acaricidal activities (Clemente et al. 2010, Gbenou et al. 2012). The main components of E. citriodora oil are citronellal, neoisopulegol, isopulegol, citronellol, citronellyl acetate, and $\beta$-caryophyllene (Zini et al. 2001, de AraujoFilho et al. 2018).

Essential oil yields of 2.3 to $5.9 \%$ have been reported from dried leaves, depending on the growing location (Moudachirou et al. 1999). Productivity is influenced by genetic factors (Doran \& Matheson 1994) and other factors such as ontogeny and age of leaf and environmental effects (Nishimura et al. 1984, Jesús et al. 2010, Brilli et al. 2013). Further, the chemical composition of essential oil has been shown to vary with harvesting time (Moudachirou et al. 1999, Tolba et al. 2015). Leaf essential oil content is higher during the wet season (April to September) in subtropical north India (Manika et al. 2012), and higher in leaves from older trees and in leaves collected in autumn than in summer (de Andrade \& Gomes 2000). Silvicultural practices such as pruning also influence leaf and essential oil productivity in E. citriodora (Wirthensohn \& Sedgley 1998). Pollarded trees in general produce more leaves than coppiced trees (Muralidharan \& Mascarenhas 1995) but for E. citriodora in Dehradun, northern India, essential oil yields were slightly better for coppiced rather than pollarded trees on a 6-month or 1-year harvest cycle (Shiva et al. 1988). 
The influence of pollarding height, tree and foliage age on the composition and yield of E. citriodora essential oil are not well understood. In this study, leaf biomass, essential oil yield and composition were measured in relation to tree age, different pruning treatments and foliage age following pollarding, with the aim of identifying silvicultural practices supporting optimal production of this essential oil.

\section{MATERIALS AND METHODS}

\section{Study location}

The study sites are located in north-east Wuming, Nanning, Guangxi Zhuang Autonomous Region $\left(22^{\circ} 59^{\prime}-23^{\circ} 33^{\prime} \mathrm{N}, 107^{\circ} 49^{\prime}-108^{\circ} 37^{\prime} \mathrm{E}\right)$. The climate in this region is subtropical monsoon with a dry season from September to April accounting for an average of $473 \mathrm{~mm}$ of precipitation, and rainy season from May to August with $767 \mathrm{~mm}$ of precipitation, adding up to an average annual total of $1240 \mathrm{~mm}$. The average annual temperature ranges from 20 to $22^{\circ} \mathrm{C}$ (National Meterological Center).

\section{Essential oil extraction and analysis}

For all experiments, the leaves were harvested in November (winter), when oil yield peaks for E. citriodora in subtropical China (Miguel et al. 2005). About $500 \mathrm{~g}$ of fresh leaves were collected from 50 E. citriodora trees chosen randomly from a 25-year-old pure species stand (planted in 1992) at the study location. Tree spacing was $2 \mathrm{~m} \times 3$ $\mathrm{m}$. The leaves were cut into $2-3 \mathrm{~cm}$ pieces, added to $800 \mathrm{~mL}$ water in a $2-\mathrm{L}$ round-bottom flask and subjected to steam distillation for 1 hour using a conventional steam distillation apparatus to extract the essential oil (following Tolba et al. 2015). E. citriodora oil on the top of the condensed water was collected, dried overnight in a desiccator and stored at $5{ }^{\circ} \mathrm{C}$. Quantitative and qualitative analysis of E. citriodora oil was carried using a gas chromatograph attached to a mass spectrometer (Wang et al. 2014) to determine the main components and their contents. The essential oil content of dried leaves (\%) was then calculated as follows:

Essential oil yield of dried leaves $(\%)=\frac{\text { Fresh leaf oil weight }}{(1-\text { fresh leaf water content })} \times 100$

\section{Qualitative analysis conditions of GC-MS}

The column was a ZB-5 silica capillary column $(30 \mathrm{~m} \times 0.25 \mathrm{~mm}, 0.25 \mu \mathrm{m})$ coupled with a mass selective detector. The column temperature was initially held at $70{ }^{\circ} \mathrm{C}$ for 5 min and was programmed to rise from 70 to $80{ }^{\circ} \mathrm{C}$ at $2{ }^{\circ} \mathrm{C} \min ^{-1}, 80$ to $85^{\circ} \mathrm{C}$ at $1{ }^{\circ} \mathrm{C} \mathrm{min}^{-1}$, 85 to $120{ }^{\circ} \mathrm{C}$ at $5{ }^{\circ} \mathrm{C} \mathrm{min}^{-1}$, and 120 to $220{ }^{\circ} \mathrm{C}$ at $10{ }^{\circ} \mathrm{C} \mathrm{min}^{-1}$. Maximum temperature was maintained for a further 3 min before cooling. The injector and detector temperatures were $250{ }^{\circ} \mathrm{C}$. The carrier gas was high purity He flowing at

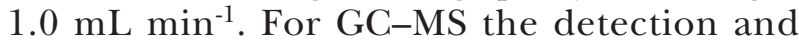
electron impact system was used with an ionisation energy of $70 \mathrm{eV}$ and a scan range from 45-350 amu. The sample size (1\% ethanol solution) was $0.5 \mu \mathrm{L}$ with a splitting ratio of 100:1.

\section{Quantitative analysis conditions of $G C$}

GC analyses of essential oil samples were performed on an gas chromatograph fitted with a flame ionisation detector, using a ZB-WAX silica capillary column $(60 \mathrm{~m} \times 0.25 \mathrm{~mm}, 0.25 \mu \mathrm{m})$. The column temperature was raised linearly from 70 to $220{ }^{\circ} \mathrm{C}$ at a rate of $2{ }^{\circ} \mathrm{C} \mathrm{min}{ }^{-1}$. The carrier gas was $\mathrm{N}_{2}$ flowing at $1.0 \mathrm{~mL} \mathrm{~min}{ }^{-1}$. The injector and detector temperatures were 200 and $250{ }^{\circ} \mathrm{C}$ respectively. The sample size was $0.5 \mu \mathrm{L}$ with a splitting ratio of 100:1.

\section{Quantifying essential oils from trees of different ages}

Fresh leaves were harvested from each of $20 \mathrm{E}$. citriodora trees that were $1,3,5,10,15,20$ and 25 years old (i.e. the stand was planted in a 5 -year succession from 1992-2012, and in 2014 and 2016). Plant spacing was $2 \mathrm{~m} \times 3 \mathrm{~m}$ in this pure species stand. Essential oils were extracted from the leaves using the procedure described earlier, then determined and quantified by GC.

\section{Quantifying essential oils from coppiced and pollarded trees}

The trees evaluated in this study were 15 years old and were planted in 2002 as a pure-species stand (20 rows of 20 trees in $1.5 \mathrm{~m} \times 1.5 \mathrm{~m}$ spacing). Fifty trees were randomly selected for each of five pruning treatments: coppicing (at ground level), 
and pollarding tree stems at heights of $0.5,1,2$ and $3 \mathrm{~m}$. One year later, fresh leaves were clipped off the regrowth and the trees pruned to the prescribed coppice or pollarding treatment for subsequent studies (not covered in this paper). The essential oils were extracted from the leaves using the procedure described earlier, then determined and quantified by GC.

\section{Quantifying essential oil production over time, after pollarding}

The trees evaluated in this study were 15 years old and were planted in 2002 as a pure-species stand (20 rows of 20 trees in $1.5 \mathrm{~m} \times 1.5 \mathrm{~m}$ spacing). All 400 trees were pollarded to $1 \mathrm{~m}$ height. Fresh leaves were collected from a random sample of 50 trees after 6 months and on year 1, 2, 3, 4 and 5 after that one-time pollarding. The essential oils were extracted from the leaves using the procedure described earlier, then determined and quantified by GC.

\section{Statistical analysis}

Statistical analyses were carried out using SPSS 19.0 software. Comparisons were made using $t$-test. The significan thresholds were 0.05 (marked by $*$ ) and $0.01(* *)$. Results are given as mean ( \pm standard deviation).

\section{RESULTS AND DISCUSSION}

\section{Composition of $E$. citriodora essential oil}

Twenty-one compounds were identified, which represented $97.2 \%$ of total compounds in the essential oil of E. citriodora. The dominant compounds included citronellal $(76.9 \%)$, citronellol $(7.5 \%)$, isopulegol $(6.4 \%)$ and neoisopulegol $(3.1 \%)$, which comprised $93.9 \%$ of oil yield (Table 1 ). The contents of citronellyl acetate $(1.1 \%)$ and $p$-menthane-3,8-diol (1.0\%) made up $2.1 \%$ while the rest of the compounds

Table 1 Quantification of the compounds detected in Eucalyptus citriodora essential oil

\begin{tabular}{|c|c|c|c|c|c|c|}
\hline No. & $\begin{array}{l}\text { Retention time } \\
(\min )\end{array}$ & Compound & Formula & $\begin{array}{l}\text { Similarity } \\
(\% o)\end{array}$ & Molecular weight & $\begin{array}{l}\text { Relative content } \\
\qquad \%)\end{array}$ \\
\hline 1 & 6.78 & $\beta$-Pinene & $\mathrm{C}_{10} \mathrm{H}_{16}$ & 892 & 136 & 0.11 \\
\hline 2 & 7.17 & $\beta$-Myrcene & $\mathrm{C}_{10} \mathrm{H}_{16}$ & 821 & 136 & 0.06 \\
\hline 3 & 8.88 & Limonene & $\mathrm{C}_{10} \mathrm{H}_{16}$ & 852 & 136 & 0.02 \\
\hline 4 & 8.89 & D-Limonene & $\mathrm{C}_{10} \mathrm{H}_{16}$ & 841 & 136 & 0.01 \\
\hline 5 & 9.01 & 1,8-Cineole & $\mathrm{C}_{10} \mathrm{H}_{18} \mathrm{O}$ & 860 & 154 & 0.09 \\
\hline 6 & 9.18 & trans- $\beta$-Ocimene & $\mathrm{C}_{10} \mathrm{H}_{16}$ & 852 & 136 & 0.13 \\
\hline 7 & 15.66 & Isopulegol & $\mathrm{C}_{10} \mathrm{H}_{18} \mathrm{O}$ & 934 & 154 & 6.37 \\
\hline 8 & 16.13 & Citronellal & $\mathrm{C}_{10} \mathrm{H}_{18} \mathrm{O}$ & 889 & 154 & 76.87 \\
\hline 9 & 16.31 & Neoisopulegol & $\mathrm{C}_{10} \mathrm{H}_{18} \mathrm{O}$ & 930 & 154 & 3.09 \\
\hline 10 & 19.84 & Citronellol & $\mathrm{C}_{10} \mathrm{H}_{18} \mathrm{O}$ & 807 & 154 & 7.46 \\
\hline 11 & 23.70 & $p$-menthane-3,8-diol & $\mathrm{C}_{10} \mathrm{H}_{20} \mathrm{O}_{2}$ & 870 & 172 & 1.03 \\
\hline 12 & 23.96 & Citronellyl acetate & $\mathrm{C}_{10} \mathrm{H}_{22} \mathrm{O}_{2}$ & 882 & 198 & 1.11 \\
\hline 13 & 24.92 & 2-Methylbenzyl acetate & $\mathrm{C}_{10} \mathrm{H}_{12} \mathrm{O}_{2}$ & 782 & 164 & 0.15 \\
\hline 14 & 25.46 & Caryophyllene & $\mathrm{C}_{15} \mathrm{H}_{24}$ & 927 & 204 & 0.50 \\
\hline 15 & 26.14 & Humulene & $\mathrm{C}_{15} \mathrm{H}_{24}$ & 859 & 204 & 0.03 \\
\hline 16 & 26.58 & $\beta$-copaene & $\mathrm{C}_{15} \mathrm{H}_{24}$ & 748 & 204 & 0.04 \\
\hline 17 & 26.83 & $\gamma$-Elemene & $\mathrm{C}_{15} \mathrm{H}_{24}$ & 810 & 204 & 0.05 \\
\hline 18 & 28.08 & Spathulenol & $\mathrm{C}_{15} \mathrm{H}_{24} \mathrm{O}$ & 780 & 220 & 0.02 \\
\hline 19 & 28.16 & Caryophylene oxide & $\mathrm{C}_{15} \mathrm{H}_{24} \mathrm{O}$ & 799 & 220 & 0.03 \\
\hline 20 & 28.22 & Globulol & $\mathrm{C}_{15} \mathrm{H}_{26} \mathrm{O}$ & 759 & 222 & 0.02 \\
\hline 21 & 31.40 & $\begin{array}{l}\text { Phthalic acid, diisobutyl } \\
\text { ester }\end{array}$ & $\mathrm{C}_{16} \mathrm{H}_{20} \mathrm{O}_{4}$ & 836 & 276 & 0.02 \\
\hline
\end{tabular}


(each $<1 \%$ ) comprised the remainder (Table 1). The four dominant compounds identified and used as indicators of oil quality in our study were the same ones reported as major E. citriodora essential oil compounds previously (Singh et al. 2011).

\section{Essential oil yield in relation to tree age}

Essential oil yield was highest from the 3- and 5 -year-old trees ( 4.4 and $4.7 \%$ respectively), which were not significantly different in yield, and thereafter negatively correlated with tree age for the 10- to 25-year-old trees in this study (Figure 1). It was noted that oil yield from the 15-year-old trees was sharply lower than all other tree ages including the 20- and 25-year-old trees and this could be due to variation in planting stock or growth conditions for these succession plantings over the 25 year period.

The most important compound citronellal was highest from the 3- and 5-year-old trees (82.6 and $82.5 \%$ respectively), which were not significantly different (Figure 1b). Citronellal yield decreased with tree age-the 25-year-old-trees had a yield of $55.5 \%$. On the other hand, citronellol yield increased with tree age-the 3- and 25-year-old trees had yields of 4.3 and $12.5 \%$ respectively (Figure 1d). Based on our results, 3- to 5-year-old trees appeared to be an optimal age range for harvesting high quality oil.

\section{Essential oil yield in relation to pruning height}

One year following the pruning treatments, foliage biomass was three times greater from 1, 2 and $3 \mathrm{~m}$ high stumps, than from coppiced trees and $0.5 \mathrm{~m}$ high stumps (Figure 2). Oil yield was highest for trees pollarded at $1 \mathrm{~m}$, although not significantly different from trees pollarded at $0.5,2$ and $3 \mathrm{~m}$. Oil yield was lowest from coppiced trees $(3.2 \%)$. Oil yield from the fresh leaves of trees pollarded at $1 \mathrm{~m}$ was $5.9 \%$ which was similar to that obtained from E. citriodora in Benin (Moudachirou et al. 1999) and CongoBrazzaville (Loumouamou et al. 2009). All pollarding treatments yielded high quantities of citronellal (77.7-81.9\%), significantly greater than yield from coppiced trees $(66.0 \%)$. The low foliage biomass from coppiced E. citriodora found in our study is in contrast with a previous study indicating that pollarded trees gave slightly less oil yields than coppiced trees (Shiva et al. 1988). While coppiced stems initially grew faster than uncut or seedling trees (Blake 1980) and produced more biomass in the first year of growth (Harrington \& Fownes 1995), several
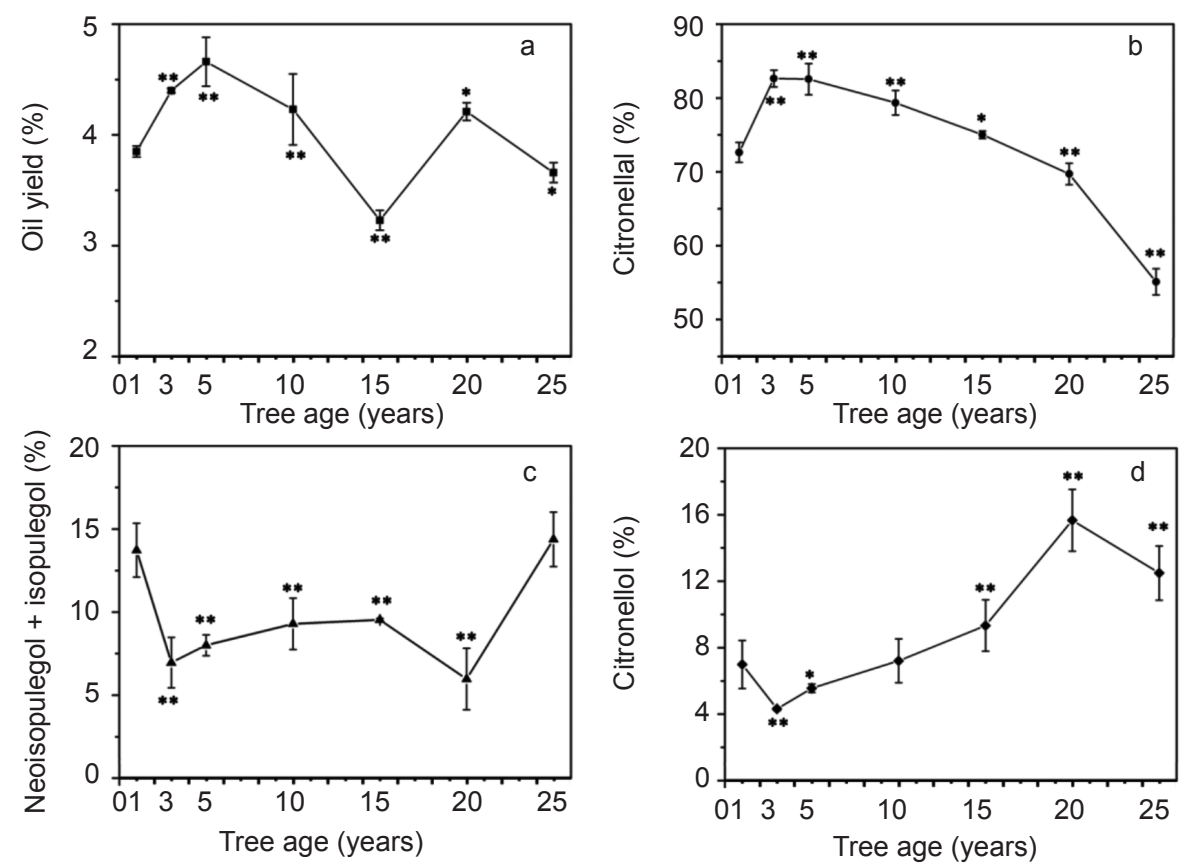

Figure 1 Mean percentage yield ( \pm standard deviation, $\mathrm{n}=20$ ) of (a) Eucalyptus citriodora essential oil, and its major compounds: (b) citronellal, (c) neoisopulegol and isopulegol, and (d) citronellol from trees of different ages; $*=\mathrm{p}<0.05, * *=\mathrm{p}<0.01$ ( $t$-test) 

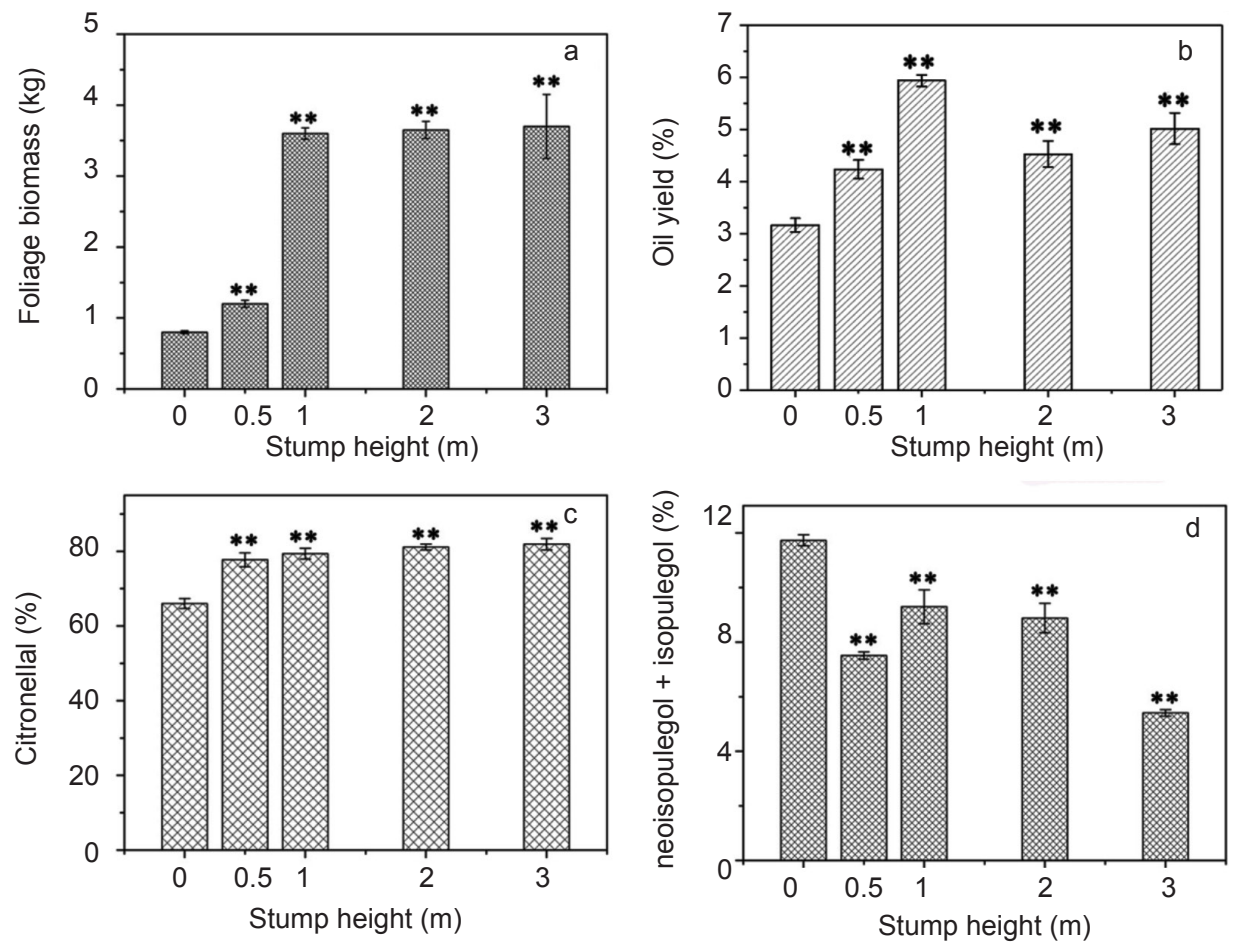

Figure 2 Mean values ( \pm standard deviation, $\mathrm{n}=50$ ) of (a) foliage biomass and (b) oil yield of E. citriodora, and of major compounds: (c) citronellal, and (d) neoisopulegol and isopulegol in relation to coppicing and pollarding; $*=\mathrm{p}<0.05, * *=\mathrm{p}<0.01$ ( $t$ - test)

authors have reported decreased stand volume, stump loss and sprout mortality that reduced productivity in coppiced eucalypt trees (Whittock et al. 2003, Zhou et al. 2017).

\section{Essential oil yield up to 5 years after pollarding}

For this field trial where all the trees were pollarded at $1 \mathrm{~m}$, oil yield was significantly higher when harvested at 12 months (5.9\%)-almost double that of the other harvest times (Figure $3 a)$. Citronellal content was also highest at 12 months after pollarding $(77.7 \%)$ while the other harvest times yielded citronellal in the range of $66.4-75.0 \%$ (Figure 3b). Citronellol content was highest in the fourth year after pollarding (16.6\%), but the content at 12 months $(10.0 \%)$ was still good. Our results partially concurred with the report by Shiva et al. (1988) that essential oil and citronellal yield was best 12 months after pruning but differred from Shiva et al. (1988) in that yield was significantly less at 6 months. Our results indicated that oil should be harvested while foliage was young (12 months) as essential oil content appeared to decrease with age.

\section{CONCLUSIONS}

The major components of E. citriodora essential oil were citronellal, citronellol, isopulegol and neoisopulegol, and their contents and oil yield changed with tree age, coppicing or pollarding height, and foliage age after pollarding. Essential oil yield and citronellal content appeared to be highest in 3- and 5-year-old trees, was higher in pollarded trees (stump heights $0.5-3.0 \mathrm{~m}$ ) than in coppiced trees, and was best in year-old foliage of pollarded trees. Based on our results, for optimal oil yield, we recommend that harvest of E. citriodora leaves should begin in the $3^{\text {rd }}$ to $5^{\text {th }}$ year after planting with a 1-year harvest interval and pollarding above $1.0 \mathrm{~m}$.

\section{ACKNOWLEDGEMENTS}

This work was financially supported by the National Key Basic Research Program of China (Grant 31860239), the Science and Technology Major Project of Guangxi (no. AA17204058-21), the Guangxi Forestry Science and Technology Project (no. 4, Guilin Scientific Research 2015), and the Fundamental Research Funds 

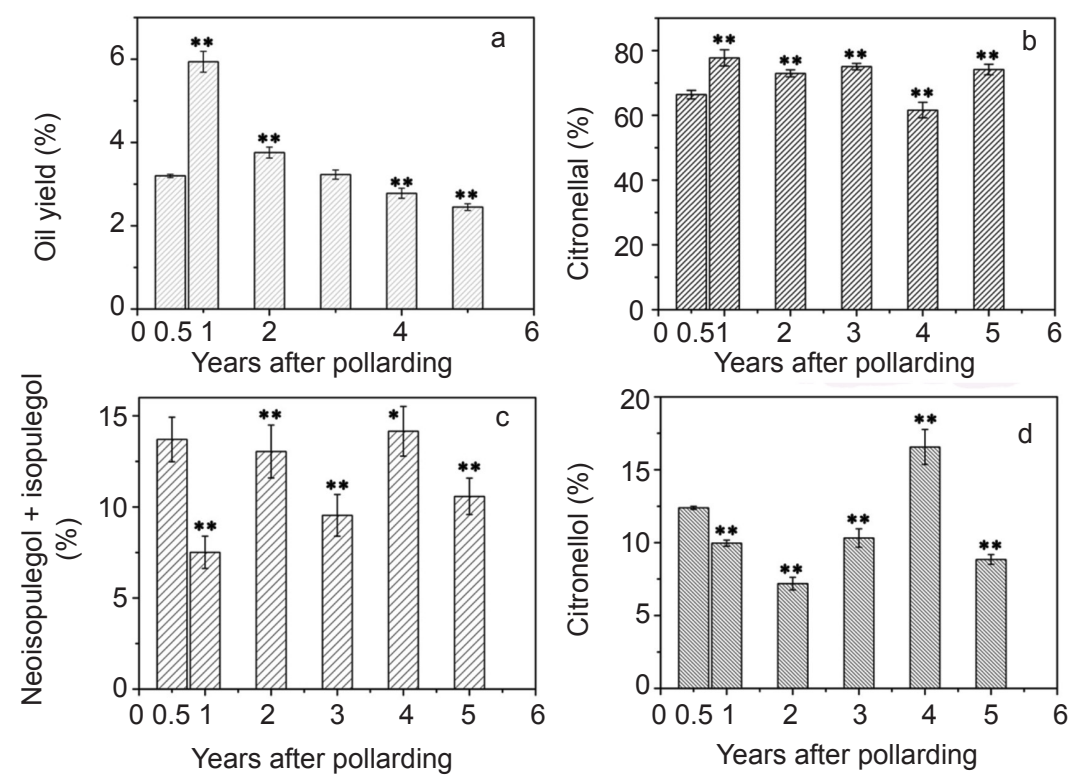

Figure 3 Mean percentage ( \pm standard deviation, $\mathrm{n}=50$ ) of E. citriodora (a) essential oil yield and its major compounds: (b) citronellal, (c) neoisopulegol and isopulegol, and (d) citronellol, after pollarding $(1 \mathrm{~m}$ stump height $) ; *=\mathrm{p}<0.05, * *=\mathrm{p}<0.01(t$-test $)$

for Guangxi Forestry Research Institute (no. LK201818). The authors thank Li L of Kunming Institute of Botany, Chinese Academy of Sciences, for her help in editing an early draft of the manuscript.

\section{REFERENGES}

BLAKE TJ. 1980. Effects of coppicing on growth rates, stomatal characteristics and water relations in Eucalyptus camaldulensis Dehn. Australian Journal of Plant Physiology 7: 81-87. https://doi.org/10.1071/ PP9800081.

Bello MO, Olabanji IO, Ibrahim AO, Yekeen tA \& Овон LM. 2013. Nutraceuticals in leaves of Eucalyptus citriodora and Eucalyptus camaldulensis. Elixir Food Science 62: 17873-17876. https://doi. org/10.13140/2.1.1578.5920.

Brilli F, Tsonev T, Mahmood T, Velikova V, Loreto F \& Centritto M. 2013. Ultradian variation of isoprene emission, photosynthesis, mesophyll conductance, and optimum temperature sensitivity for isoprene emission in water-stressed Eucalyptus citriodora saplings. Journal of Experimental Botany 64: 519-528. https://doi.org/10.1093/jxb/ers353.

Clemente MA, De Oliviera MCM, Scoralik MG, Gomes FT, De Azevedo PMC \& Daemon E. 2010. Acaricidal activity of the essential oils from Eucalyptus citriodora and Cymbopogon nardus on larvae of Amblyomma cajennense (Acari: Ixodidae) and Anocentor nitens (Acari: Ixodidae). Parasitology Research 107: 987-992. https://doi.org/10.1007/s00436-010-1965-0.

Doran JC \& Matheson. 1994. Genetic parameters and expected gains from selection for monoterpene yields in Petford Eucalyptus camaldulensis. New Forest 8: $155-167$.

Gbenou JD, Ahounou JF, Akakpo HB et al. 2012. Phytochemical composition of Cymbopogon citrates and Eucalyptus citriodora essential oils and their antiinflammatory and analgesic properties on Wistar rats. Molecular Biology Reports 40: 1127-1134. https:/ / doi.org/10.1007/s11033-012-2155-1.

HarRington RA \& Fownes JH. 1995. Radiation interception and growth of planted and coppice stands of four fast-growing tropical trees. Journal of Applied Ecology 32:1-8. https://www.jstor.org/stable/2404410.

Jesús OV, Luz SN \& ELENA ES. 2010. Bioactivity against Tribolium castaneum Herbst (Coleoptera: Tenebrionidae) of Cymbopogon citratus and Eucalyptus citriodora essential oils grown in Colombia. Pest Management Science 66: 664-668. https://doi.org/10.1002/ps.1927.

DE ANDRADE AM \& Gomes SDS. 2000. Influence of some non genetic factors on the essential oil leaves. Floresta $e$ Ambiente 7: 181-189.

de Araujo-Filho JV, Ribeiro WLC, Andre WPP et al. 2018. Effects of Eucalyptus citriodora essential oil and its major component, citronellal, on Haemonchus contortus isolates susceptible and resistant to synthetic anthelmintics. Industrial Crops and Products 124: 294-299. https://doi.org/10.1016/j. indcrop.2018.07.059.

Loumouamou AN, Silou TH, Mapola G, Chalchat JC \& Figueredo G. 2009. Yield and composition of essential oils from Eucalyptus citriodora $\times$ Eucalyptus torelliana, a hybrid species growing in Congo-Brazzaville. Journal of Essential Oil Research 21: 295-299. https://doi.org /10.1080/10412905.2009.9700175.

Manika N, Mishra P, Kumar N, Chanotiya CS \& Bagchi GD. 2012. Effect of season on yield and composition of the essential oil of Eucalyptus citriodora Hook. leaf 
grown in sub-tropical conditions of North India. Journal of Medicinal Plants Research 6: 2875-2879. https://doi.org/10.5897/JMPR011.1611.

Miguel MG, Duarte J, Figueiredo AC, Barroso JG \& Pedro LG. 2005. Thymus carnosusboiss.: effect of harvesting period, collection site and type of plant material on essential oil composition. Journal of Essential Oil Research 17: 422-426. https://doi.org/10.1080/104 12905.2005.9698950.

Moudachirou M, Gbenou JD, Chalchat JC, Chabard JL \& LARTigue C. 1999. Chemical composition of essential oils of eucalyptus from Bénin: Eucalyptus citriodora and E. camaldulensis. Influence of location, harvest time, storage of plants and time of steam distillation. Journal of Essential Oil Research11: 109-118. https:// doi.org/10.1080/10412905.1999.9701085.

Muralidharan EM \& Mascarenhas AF. 1995. Somatic Embryogenesis in in Eucalyptus. Somatic Embryogenesis in Woody Plants. Springer Netherlands.

Nishimura H, Nakamura T \& Mizutani J. 1984. Allelopathic effects of $p$-menthane-3,8-diols in Eucalyptus citriodora. Phytochemistry 23: 2777-2779. https://doi. org/10.1016/0031-9422(84)83014-9.

Singh HP, Shalinder K, Negi K, Kumari S, Saini V, Batish DR \& KoHLI RK. 2011. Assessment of in vitro antioxidant activity of essential oil of Eucalyptus citriodora (lemon-scented eucalypt; Myrtaceae) and its major constituents. LWT-Food Science and Technology 48: 237-247. https://doi.org/10.1016/j.lwt.2012.03.019.

Shiva MP, Jaffer KR, Mehra SN, Sachidanand, Singh NP \& ChAudhari DC. 1988. Trend of essential oil yield and citronellal content in from coppiced and pollarded crops at different periodicity at Dehradun. Indian Perfumer 32: 29-39. https://www.cabi.org/isc/ abstract/19890354031.
Tolba H, Moghrani H, Benelmouffok A, Kellou D \& Maachi R. 2015. Essential oil of Algerian Eucalyptus citriodora: chemical composition, antifungal activity. Journal de Mycologie Médicale 25: 128-133. https://doi. org/10.1016/j.mycmed.2015.10.009.

Tripathi P, Dubey NK \& Shukla AK. 2008. Use of some essential oils as post-harvest botanical fungicides in the management of grey mould of grapes caused by Botrytis cinerea. World Journal of Microbiology $\mathcal{E}$ Biotechnology 24:39-46. https://doi.org/10.1007/ s11274-007-9435-2.

WAng C, YAng J, Zhao P et Al. 2014. Chemical constituents from Eucalyptus citriodora Hook leaves and their glucose transporter 4 translocation activities. Bioorganic E Medicinal Chemistry Letters 24: 30963099. https://doi.org/10.1016/j.bmcl.2014.05.014.

Whittock SP, Apiolaza CM, Kelly CM \& Potts BM. 2003. Genetic control of coppice and lignotuber development in Eucalyptus globulus. Australian Journal of Botany 51: 57-67. https://doi.org/10.1071/ BT02049.

WirTHENSOHN MG \& SEDGley M. 1998. Effect of pruning on regrowth of cut foliage stems of seventeen Eucalyptus species. Australian Journal of Experimental Agriculture 38: 631-636. https://doi.org/10.1071/EA98053.

Zhou XG, Ye D, Zhu HG et al. 2017. Effects of second rotation seedlings and coppice on understorey vegetation and timber production of Eucalyptus plantations. Journal of Tropical Forest Science 29: 54-68.

Zini CA, Augusto F, Christensen E, Smith BPC, Caramao EB \& Pawliszin J. 2001. Monitoring biogenic volatile compounds emitted by Eucalyptus citriodora using SPME. Analytical Chemistry 73: 4729-4735. https:// doi.org/10.1021/ac0103219. 